\title{
Evaluation of Selected Segregating Populations of Indian Rapeseed (Brassica rapa L.) for Yield and Yield Related Traits
}

\author{
Smrita Gogoi* and Purna K. Barua
}

Department of Plant Breeding and Genetics, Assam Agricultural University, Jorhat-785013, Assam, India

*Corresponding author

\section{A B S T R A C T}

\begin{tabular}{|l|}
\hline K e y w o r d s \\
$\begin{array}{l}\text { Toria, Yellow sarson, } \\
\text { Seed yield/plant, Genetic } \\
\text { variation, Heritability, } \\
\text { Genetic advance }\end{array}$ \\
\hline Article Info \\
\hline $\begin{array}{l}\text { Accepted: } \\
10 \text { August } 2018 \\
\text { Available Online: } \\
\text { 10 September } 2018\end{array}$ \\
\hline
\end{tabular}

Toria is the predominant oilseed crop of Assam, but productivity is very low compared to all India average. Therefore, continued efforts are necessary to achieve high seed yield through breeding high yielding varieties. The present study was conducted to evaluate the segregating populations of some toria $\mathrm{x}$ yellow sarson crosses for yield and related traits. During Rabi 2015-16, 21 populations consisting of 5 parents, $3 \mathrm{~F}_{1} \mathrm{~s}$ and $13 \mathrm{~F}_{3} \mathrm{~s}$ were grown. Highly significant differences were observed among the populations for different yield attributing characters. High genotypic variation was observed for number of secondary branches per plant, seed yield/plant, biological yield/plant and harvest index. High heritability was observed for days to $50 \%$ flowering, seed yield per plant and plant height. High genetic advance was recorded for number of secondary branches, seed yield/ plant, biological yield/ plant, harvest index and days to $50 \%$ flowering. Jeuti was early maturing genotype. The genetic variation present in toria and yellow sarson populations could be utilized in breeding useful varieties of toria and yellow sarson types.

\section{Introduction}

Rapeseed (Brassica napus L. and B. rapa L.) and mustard (B. juncea) are the major oilseed Brassica species in India. Crop Brassicas are of great importance as vegetables, oilseeds and fodder throughout the world. The oleiferous Brassica species play an important role for vegetable oil production worldwide. From nutritional point of view, fats and oils in our diet are needed for calories and translocation of fat soluble vitamins. At present, rapeseed-mustard is the third most important source of edible oils in the world after palm oil and soybean, and it is used for both nutritional and industrial purposes (FAO, 2014). Brassica oilseed production has increased over the last 50 years (FAO, 2014). The largest acreage of Brassica oilseeds is found in India, followed by China and Canada. The highest seed yields are reported from Europe (France, Germany and the UK) with average yields of about 3.0 tonnes/ha, more than twice the seed yields obtained in Canada and Australia (Rakow, 2004).

In India, rapeseed-mustard is the second most important oilseed crop after soybean. It is an important source of edible oil in Indian diet especially in Eastern and North-Western India. 
Toria and to a lesser extent Yellow sarson (Brassica rapa L.) are grown in Assam. It is the most important oilseed in Assam with acreage of 2.57 lakh hectares producing 1.45 lakh tonnes resulting in average yield of 564 $\mathrm{kg} / \mathrm{ha}$. Assam accounts for 3.9 percent and 1.9 percent of the total Indian acreage and production, respectively (DRMR, 2016). Toria is characterized by hollow and weak stem, shallow roots, low biological yield, but high harvest index and short crop duration. On the other hand Yellow sarson has erect growth habit, deeper roots, solid stems, high biological yield but low harvest index (Barua, 1992). Attempts have been made to recombine the desirable yield component characters of Toria and Yellow sarson towards development of high yielding varieties of Toria and Yellow sarson which are highly cross compatible. However, continued efforts are necessary to achieve high seed yield through recombination breeding. The present study was to evaluate some segregating populations of Toria-Yellow sarson crosses for yield and related characters.

\section{Materials and Methods}

The investigation was carried out at the experimental area of the Department of Plant Breeding and Genetics, Assam Agricultural University, Jorhat. The site is located at $26^{0} 44^{\prime}$ north latitude and $94^{0} 10^{\prime}$ east longitude having an elevation of $91 \mathrm{~m}$ above the mean sea level (www.aau.ac.in). Temperature recorded during period of experiment was between 9.4$28.8^{\circ} \mathrm{c}$ with relative humidity $55-99 \%$ with low rainfall and bright sunshine hours. Twenty one entries were sown on $5^{\text {th }}$ November 2015 in randomized block design with three replications during rabi season 2015-16. Each plot contained 4 rows measuring $4 \mathrm{~m}$ in length. Row to row spacing was $30 \mathrm{~cm}$ and plant spacing within row was adjusted to 10$15 \mathrm{~cm}$ by thinning at seedling stage. The experimental material comprised of five varieties and three $F_{1}$ and thirteen $F_{3}$ populations, as given in Table 1. Well decomposed cow dung was applied @ 2 t/ha along with $\mathrm{N}: \mathrm{P}_{2} \mathrm{O}_{5}: \mathrm{K}_{2} \mathrm{O} @ 60: 40: 40 \mathrm{~kg} / \mathrm{ha}$ in the form of urea, single super phosphate and muriate of potash. Irrigation of the experimental fields was done by sprinkling water manually six times, twice at sowingseedling stage, twice at active vegetative, and twice during flowering and pod filling stages. Manual weeding and thinning were done during vegetative growth period, 15-20 days after sowing. Malathion 5 percent dust was applied by mixing with cow dung one week after germination to protect the seedlings from ants. At siliqua formation stage of the crop Rogor 30 EC was sprayed once to keep aphid population under control. No other serious pest and diseases were observed.

Observations were recorded on ten random plants per plot for 13 quantitative different characters (as in Table 4) related to growth and yield. Days to 50 percent flowering and maturity were observed on plot basis. Stem solidness/ hollowness was recorded by pressing between fingers at the stage of maturity. The plot mean data were subjected to analysis of variance for each character following standard statistical procedure in the fixed model (Gomez and Gomez, 1984). Mean performance was compared by critical differences at 5 and 1 percent level of significance. Genotypic coefficient of variation, phenotypic coefficient of variation, heritability and genetic advance were estimated by standard biometrical procedures (Dabholkar, 1999). All calculations were done by using MS Excel 2007.

\section{Results and Discussion}

The presence of variability is prerequisite for any breeding programme. In the present study, significant variation was observed among the populations for all yield and component traits recorded (Table 2). High genotypic and 
phenotypic coefficients of variation were recorded for number of secondary branches, seed yield per plant, biological yield per plant and harvest index (Table 3). From the ranges of mean values, it was observed that there were large variations for all the characters, though coefficients of variation were not large. High broad sense heritability was observed for days to $50 \%$ flowering, seed yield per plant, plant height, secondary branches per plant, harvest index and biological yield per plant. High genetic advance was recorded for number of secondary branch, seed yield per plant, biological yield per plant, harvest index and days to $50 \%$ flowering. Thus for days to $50 \%$ flowering, seed yield per plant, plant height, secondary branches per plant, harvest index and biological yield per plant high heritability as well as high genetic advance were observed. High heritability and high genetic advance are indication of additive gene effects for such traits (Panse, 1957). Similar findings were reported in the inheritance of these traits in rapeseed (Kahrizi and Allahvarand, 2012; Khan et al., 2013; Halder et al., 2014). Therefore additive genetic effects were important in the inheritance of these characters. Non-additive gene effects were probably more influential in the inheritance of the other traits. Less difference between GCV and PCV for days to $50 \%$ flowering indicated that the genotypes have relatively less adaptive variation for flowering, as also inferred by Jahan (2014).

From the present investigation high heritability with moderate genetic advance was recorded for plant height. Similar result was observed by Saifullah (2012), whereas Naznin (2013) found high heritability with low genetic advance and Halder et al., (2014) observed moderate heritability with low genetic advance for this trait. For number of primary branches per plant low heritability with low genetic advance was observed.
However, for number of secondary branches per plant moderate heritability with high genetic advance was recorded. High GCV was also observed for this trait. Jahan et al., (2014) reported similar results in their study. Low heritability with moderate genetic advance was recorded for main shoot length and moderate heritability with moderate genetic advance for number of siliquae on main shoot. Moderate heritability was also recorded by Khan et al., (2008) for main shoot length. Ghosh and Gulati (2001) reported high heritability for number of pods per main shoot in Indian mustard. For number of seeds per siliqua moderate heritability with moderate genetic advance and moderate GCV was recorded. Similar results were reported by Jahan et al., (2014). Halder et al., (2014) observed moderate heritability with moderate genetic advance for number of seeds per siliqua and thousand seed weight. In the present investigation also similar results were recorded for thousand seed weight. On the other hand, low heritability with low genetic advance was observed for maximum root length.

For seed yield per plant, high heritability with high genetic advance was recorded. High heritability was also recorded by Ullah et al., (2015) for seed yield per plant. High broad sense heritability for seed yield per plant indicated more genetic control and less environmental influence on this trait. Similar findings were reported by Ali et al., (2003), Tahira et al., (2006), Aytac and Kinaci (2009) and Singh and Singh (2012) and they also observed high heritability for seed yield per plant. Similarly, relatively high heritability with high genetic advance was recorded for biological yield per plant and harvest index. The results from present investigation showed considerable variations among the rapeseed populations for yield and yield attributing characters revealing good scope for breeding a high yielding variety of rapeseed. 
Table.1 Experimental populations grown during Rabi 2015-16

\begin{tabular}{|c|c|c|c|c|}
\hline SN & & Population & Ecotype & Source \\
\hline 1. & & YSH401 & Yellow sarson & CCS HAU, Hisar \\
\hline 2. & & NRCYS05-03 & Yellow sarson & DRMR, Bharatpur \\
\hline 3. & & TS38 & Toria & RARS, Shillongani, AAU \\
\hline 4. & & Jeuti & Toria & Dept of PBG, AAU \\
\hline 5. & & B9 & Yellow sarson & ICR Farm, AAU \\
\hline 6. & JT 12-1 & TS38 x Jeuti $F_{3}$ & Toria & Dept of PBG, AAU \\
\hline 7. & JT 12-2-1 & TS67 x YSH401 F 3 Sel-1 & Toria $\mathrm{x}$ yellow & Dept of PBG, AAU \\
\hline 8. & JT $12-3$ & TS67 x NRCYS05-03 F 3 & Toria $\mathrm{x}$ yellow & Dept of PBG, AAU \\
\hline 9. & JT 12-2-2 & TS67 x YSH401F 3 Sel-2 (early) & Toria $\mathrm{x}$ yellow & Dept of PBG, AAU \\
\hline 10. & JT 14-1 & Jeuti x YSH401 $\mathrm{F}_{1}$ & Toria $\mathrm{x}$ yellow & Dept of PBG, AAU \\
\hline 11. & JT 14-1 & Jeuti x B9 $F_{1}$ & Toria $\mathrm{x}$ yellow & Dept of PBG, AAU \\
\hline 12. & JT $12-5$ & NRCYS05-03 x Jeuti $F_{3}$ & Yellow sarson $\mathrm{x}$ toria & Dept of PBG, AAU \\
\hline 13. & JT $12-6$ & NRCYS05-03 x TS38 $F_{3}$ & Yellow sarson $\mathrm{x}$ toria & Dept of PBG, AAU \\
\hline 14. & JYS 12-1 & NRCYS05-03 x B9 F 3 & Yellow sarson $\mathrm{x}$ yellow sarson & Dept of PBG, AAU \\
\hline 15. & JT $12-7$ & YSH401 x TS38 $\mathrm{F}_{3}$ & Yellow sarson $\mathrm{x}$ toria & Dept of PBG, AAU \\
\hline 16. & JT $12-8$ & YSH401 x Jeuti F 3 & Yellow sarson $\mathrm{x}$ toria & Dept of PBG, AAU \\
\hline 17. & JYS 12-2-1 & YSH401 x B9 $F_{3}$ Sel-1 (brown seeds) & Yellow sarson $\mathrm{x}$ yellow sarson & Dept of PBG, AAU \\
\hline 18. & JYS 12-2-2 & YSH401 x B9 F $\mathrm{F}_{3}$ Sel-2 (erect pods) & Yellow sarson $\mathrm{x}$ yellow sarson & Dept of PBG, AAU \\
\hline 19. & JYS 14-1 & YSH401 x B9 $F_{1}$ & Yellow sarson x yellow sarson & Dept of PBG, AAU \\
\hline 20. & JYS $12-2-3$ & YSH401 x B9 F F Sel-3 (yellow seed) & Yellow sarson $\mathrm{x}$ yellow sarson & Dept of PBG, AAU \\
\hline 21. & JYS 12-2-4 & YSH401 x B9 F 3 Sel-4 (brown seed, early) & Yellow sarson $\mathrm{x}$ yellow sarson & Dept of PBG, AAU \\
\hline
\end{tabular}

\begin{tabular}{|c|c|c|}
\hline SN & Designation of population & Pedigree \\
\hline 1. & YSH401 & Selection from local germplasm \\
\hline 2. & NRCYS 05-03 & Selection from local germplasm IC 355419 \\
\hline 3. & TS38 & Recurrent selection in M27 \\
\hline 4. & Jeuti & M27 x B9 \\
\hline 5. & B9 & Selection from local germplasm of Assam \\
\hline 6. & JT 12-1 & TS38 x Jeuti $\left(\mathrm{F}_{3}\right)$ \\
\hline 7. & JT 12-2-1 & TS67 x YSH401 $\left(\mathrm{F}_{3}\right)$ sel-1 \\
\hline 8. & JT 12-3 & TS67 x NRCYS05-03( $\left.\mathrm{F}_{3}\right)$ \\
\hline 9. & JT 12-2-2 & TS67 x YSH401( $\left.\mathrm{F}_{3}\right)$ sel-2 (early) \\
\hline 10. & JT 14-1 & Jeuti $x$ YSH401( $\left.F_{1}\right)$ \\
\hline 11. & JT 14-2 & Jeuti x B9 $\left(F_{1}\right)$ \\
\hline 12. & JT $12-4$ & NRCYS05-03 x Jeuti $\left(\mathrm{F}_{3}\right)$ \\
\hline 13. & JT $12-5$ & NRCYS05-03 x TS38 $\left(\mathrm{F}_{3}\right)$ \\
\hline 14. & JYS 12-1 & NRCYS05-03 x B9 $\left(\mathrm{F}_{3}\right)$ \\
\hline 15. & JT 12-6 & YSH401 x TS38 $\left(\mathrm{F}_{3}\right)$ \\
\hline 16. & JT 12-7 & YSH401 x Jeuti $\left(\mathrm{F}_{3}\right)$ \\
\hline 17. & JYS 12-2-1 & YSH401 x B9 $\left(\mathrm{F}_{3}\right)$ Sel-1 (brown seeds) \\
\hline 18. & JYS 12-2-2 & YSH401 x B9 $\left(\mathrm{F}_{3}\right)$ sel-2 (erect pods) \\
\hline 19. & JYS 14-1 & YSH401 x B9 $\left(F_{1}\right)$ \\
\hline 20. & JYS $12-2-3$ & YSH401 x B9 $\left(F_{3}\right)$ sel-3 (yellow seed) \\
\hline 21. & JYS $12-2-4$ & YSH401 x B9 $\left(F_{3}\right)$ sel-4 (brown seed, early \\
\hline
\end{tabular}


Table.2 Analysis of variance (mean square) for seed yield and related traits in rapeseed

\begin{tabular}{|c|c|c|c|c|c|c|c|c|c|c|c|c|c|c|}
\hline $\begin{array}{l}\text { Sources of } \\
\text { variation }\end{array}$ & df & $\begin{array}{l}\text { Days to } \\
50 \% \\
\text { flower }\end{array}$ & $\begin{array}{l}\text { Days to } \\
\text { maturity }\end{array}$ & $\begin{array}{c}\text { Plant } \\
\text { height }\end{array}$ & $\begin{array}{c}\text { Primary } \\
\text { branches } \\
\text { per } \\
\text { plant }\end{array}$ & $\begin{array}{c}\text { Secondary } \\
\text { branches } \\
\text { per plant }\end{array}$ & $\begin{array}{l}\text { Main } \\
\text { shoot } \\
\text { length }\end{array}$ & $\begin{array}{c}\text { Siliquae } \\
\text { on } \\
\text { main } \\
\text { shoot }\end{array}$ & $\begin{array}{l}\text { Seeds } \\
\text { per } \\
\text { siliqua }\end{array}$ & $\begin{array}{c}\text { Maximum } \\
\text { root } \\
\text { length }\end{array}$ & $\begin{array}{c}1000 \\
\text { seed } \\
\text { weight }\end{array}$ & $\begin{array}{c}\text { Seed } \\
\text { yield } \\
\text { per } \\
\text { plant }\end{array}$ & $\begin{array}{l}\text { Biological } \\
\text { yield per } \\
\text { plant }\end{array}$ & $\begin{array}{c}\text { Harvest } \\
\text { index }\end{array}$ \\
\hline Replications & 2 & $20.63 * *$ & $26.05 * *$ & $71.84 * *$ & 0.44 & 0.38 & $17.62 * *$ & $5.80 * *$ & $17.20 * *$ & $27.13 * *$ & 0.13 & 0.09 & 0.06 & 16.55 \\
\hline Genotypes & 20 & $82.05 * *$ & $40.45 * *$ & $306.69 * *$ & $2.92 * *$ & $7.01 * *$ & $38.74 * *$ & $45.74 * *$ & $39.33 * *$ & $6.83 * *$ & $1.15^{* *}$ & $10.47 * *$ & $27.51 * *$ & $308.85 * *$ \\
\hline Error & 40 & 3.23 & 6.06 & 22.81 & 0.89 & 0.42 & 8.42 & 5.29 & 6.74 & 2.14 & 0.21 & 0.69 & 2.38 & 24.51 \\
\hline CV \% & & 5.17 & 2.72 & 4.20 & 16.10 & 21.18 & 6.10 & 6.33 & 12.92 & 6.70 & 10.98 & 15.25 & 13.14 & 10.56 \\
\hline
\end{tabular}

Table.4 Mean performance of different populations for seed yield and related traits in rapeseed

\begin{tabular}{|c|c|c|c|c|c|c|c|c|c|c|c|c|c|c|}
\hline Population & $\mathbf{S T}^{*}$ & DF & DM & PH & PB & SB & MSL & SMS & SSQ & MRL & TSW & SYP & BYP & HI \\
\hline YSH401 & S & 43.7 & 91.7 & 123.0 & 5.67 & 0.83 & 51.17 & 35.90 & 21.27 & 23.33 & 4.67 & 5.38 & 10.81 & 44.89 \\
\hline NRCYS 05-03 & $S$ & 35.3 & 96.3 & 124.4 & 6.00 & 0.83 & 46.12 & 39.37 & 31.27 & 24.20 & 4.13 & 5.17 & 13.23 & 34.50 \\
\hline TS38 & $\mathrm{H}$ & 33.0 & 88.7 & 91.1 & 6.00 & 6.70 & 46.67 & 35.30 & 18.60 & 22.77 & 3.30 & 7.03 & 14.38 & 44.46 \\
\hline Jeuti & $\mathrm{H}$ & 30.3 & 86.0 & 96.3 & 4.00 & 1.33 & 44.23 & 29.50 & 18.93 & 21.03 & 4.17 & 4.59 & 9.99 & 41.59 \\
\hline B9 & S & 34.0 & 94.7 & 119.4 & 5.33 & 0.83 & 42.45 & 26.10 & 24.00 & 20.07 & 3.90 & 4.53 & 8.49 & 47.62 \\
\hline JT 12-1 & $\mathrm{H}$ & 31.3 & 90.0 & 107.1 & 5.67 & 1.77 & 43.00 & 36.80 & 21.47 & 22.87 & 3.33 & 5.24 & 9.45 & 50.19 \\
\hline JT 12-2-1 & $\mathrm{H}$ & 42.7 & 93.7 & 120.9 & 8.00 & 4.57 & 52.60 & 34.40 & 18.53 & 22.00 & 4.73 & 7.74 & 15.13 & 45.98 \\
\hline JT 12-3 & $\mathrm{H}$ & 31.7 & 89.0 & 97.9 & 4.33 & 2.50 & 43.03 & 31.40 & 16.73 & 17.93 & 4.37 & 2.86 & 6.49 & 39.19 \\
\hline JT 12-2-2 & $\mathrm{H}$ & 34.0 & 88.7 & 108.6 & 5.00 & 1.40 & 47.27 & 33.00 & 20.53 & 21.67 & 3.50 & 5.46 & 10.68 & 46.48 \\
\hline JT 14-1 & $\mathrm{H}$ & 32.0 & 89.7 & 110.3 & 5.00 & 1.17 & 47.30 & 35.77 & 16.13 & 20.67 & 4.30 & 4.24 & 8.43 & 45.80 \\
\hline JT 14-2 & $\mathrm{H}$ & 40.3 & 89.0 & 118.1 & 4.67 & 2.00 & 53.63 & 38.10 & 18.00 & 23.53 & 4.70 & 6.32 & 11.24 & 51.27 \\
\hline JT 12-4 & $\mathrm{H}$ & 32.3 & 88.3 & 107.8 & 6.00 & 0.90 & 46.82 & 40.07 & 19.60 & 22.27 & 4.13 & 5.09 & 8.76 & 53.12 \\
\hline JT 12-5 & $\mathrm{H}$ & 43.0 & 95.3 & 118.1 & 6.67 & 3.33 & 52.85 & 41.33 & 18.93 & 20.33 & 4.70 & 10.43 & 17.83 & 53.51 \\
\hline JYS 12-1 & S & 30.7 & 89.7 & 129.0 & 7.00 & 0.87 & 49.57 & 38.57 & 17.93 & 21.60 & 4.60 & 3.33 & 13.66 & 19.58 \\
\hline JT 12-6 & $\mathrm{H}$ & 33.0 & 92.0 & 117.5 & 7.00 & 1.37 & 45.63 & 36.33 & 18.07 & 21.27 & 4.97 & 2.88 & 12.86 & 17.36 \\
\hline JT 12-7 & $\mathrm{H}$ & 32.7 & 88.3 & 113.5 & 6.00 & 0.83 & 47.53 & 37.63 & 17.87 & 22.67 & 4.63 & 4.30 & 13.03 & 28.08 \\
\hline JYS 12-2-1 & S & 32.7 & 94.3 & 125.6 & 6.67 & 3.53 & 54.55 & 40.83 & 20.33 & 21.27 & 3.50 & 5.85 & 12.63 & 41.22 \\
\hline JYS 12-2-2 & $\mathrm{S}$ & 30.7 & 87.3 & 110.8 & 5.00 & 1.53 & 45.37 & 36.43 & 19.60 & 20.80 & 3.43 & 4.62 & 11.68 & 34.96 \\
\hline JYS 14-1 & S & 47.0 & 100.0 & 118.3 & 6.33 & 0.60 & 44.80 & 35.33 & 27.67 & 23.33 & 5.47 & 8.29 & 15.00 & 50.35 \\
\hline JYS 12-2-3 & S & 37.3 & 90.3 & 123.6 & 6.33 & 1.37 & 48.83 & 41.37 & 19.27 & 20.87 & 4.73 & 7.12 & 15.94 & 39.69 \\
\hline JYS 12-2-4 & S & 34.3 & 87.3 & 109.3 & 6.67 & 3.13 & 46.03 & 39.17 & 17.33 & 23.93 & 3.43 & 3.90 & 7.11 & 49.79 \\
\hline Mean & & 34.8 & 90.6 & 113.8 & 5.87 & 1.97 & 47.59 & 36.32 & 20.10 & 21.83 & 4.22 & 5.45 & 11.75 & 41.89 \\
\hline SE (m) & & 1.0 & 1.4 & 2.8 & 0.37 & 0.32 & 1.67 & 1.33 & 1.50 & 0.84 & 0.27 & 0.48 & 0.89 & 2.86 \\
\hline $\mathrm{CD}(\mathrm{P}=0.05)$ & & 3.0 & 4.1 & 7.9 & 1.56 & 0.91 & 4.79 & 3.80 & 4.29 & 2.41 & 0.77 & 1.37 & 2.55 & 8.17 \\
\hline $\mathrm{CD}(\mathrm{P}=0.01)$ & & 4.0 & 5.4 & 10.5 & 2.09 & 1.22 & 6.40 & 5.08 & 5.73 & 3.23 & 1.02 & 1.83 & 3.41 & 10.93 \\
\hline
\end{tabular}

*Stem texture: $\mathrm{S}=$ Solid, $\mathrm{H}=$ Hollow 
Table.3 Estimates of genetic parameters for various characters for seed yield and Related traits in rapeseed

\begin{tabular}{|l|c|c|c|c|c|}
\hline Characters & Range & GCV (\%) & PCV (\%) & $\begin{array}{c}\text { Heritability } \\
(\%)\end{array}$ & $\begin{array}{c}\text { Genetic } \\
\text { advance }(\%)\end{array}$ \\
\hline Days to 50\% flowering & $30.3-47.0$ & 15.96 & 16.78 & 90.50 & 31.29 \\
\hline Days to maturity & $86.0-100.0$ & 4.33 & 5.11 & 71.77 & 7.56 \\
\hline Plant height (cm) & $91.1-129.0$ & 8.54 & 9.52 & 80.58 & 15.80 \\
\hline No. of primary branches per plant & $4.0-8.0$ & 13.98 & 21.32 & 42.97 & 18.87 \\
\hline No. of secondary branches per plant & $0.6-6.7$ & 35.23 & 39.74 & 78.58 & 64.33 \\
\hline Main shoot length (cm) & $42.5-54.5$ & 6.68 & 9.04 & 54.57 & 10.17 \\
\hline No. of siliquae on main shoot & $26.1-41.4$ & 10.11 & 11.93 & 71.83 & 17.65 \\
\hline No. of seeds per siliqua & $16.1-31.3$ & 16.40 & 20.88 & 61.69 & 26.53 \\
\hline Maximum root length (cm) & $17.9-24.2$ & 5.73 & 8.82 & 42.20 & 7.67 \\
\hline 1000 seed wt (g) & $3.30-4.70$ & 13.22 & 17.18 & 59.20 & 20.95 \\
\hline Seed yield per plant (g) & $2.86-10.43$ & 33.15 & 36.49 & 82.54 & 62.05 \\
\hline Biological yield per plant (g) & $6.49-17.83$ & 24.62 & 27.91 & 77.83 & 44.75 \\
\hline Harvest index (\%) & $17.4-53.5$ & 20.76 & 23.29 & 79.45 & 38.13 \\
\hline
\end{tabular}

The mean performances of the twenty one populations are presented in (Table 4). Jeuti was the earliest flowering and maturing population.TS38, JT 12-1, JT 12-3, JT 12- JT 12-7, JYS 12-2-2 and JYS 12-2-4 are other early flowering and maturing populations. On the other hand JYS 14-1 was the late in flowering and maturity. TS 38 was a short statured genotype followed by Jeuti and JT 12-3. All other genotypes are taller and JYS 12-1 was the tallest with a height of $129 \mathrm{~cm}$. All the Yellow sarson varieties and their derivatives were characterized with solid stem and the Toria genotypes with hollow stem (Table 4). NRCYS 05-03 produced the longest roots $(24.2 \mathrm{~cm})$ followed by JYS 12 2-4, JT 14-2, JYS 14-1, YSH 401, JT 12-1, JT 12-7, TS 38, which were at par with NRCYS 05-03.

More number of primary branches was observed for the populations JT 12-2-1, JYS 12-1 and JT 12-6. The highest number of secondary branches was observed for TS38 (6.7) followed by JT 12-2-1, JYS 12-2-1 and JYS 12-2-4 were other populations with more secondary branches. In case of main shoots, among the populations JYS 12-2-1, JT 14-2, JT 12-5, JT 12-2-1 and YSH401 had long main shoots (51.17 to $54.55 \mathrm{~cm}$ ) and JYS 122-3 produced the highest number of siliqua on main shoot (41.37) followed by JT 12-5, JYS 12-2-1, JT 12-4, NRCYS05-03, and JYS 122-4. JYS 12-2-1 possess long main shoot as well as more siliqua on main shoot, which ultimately contribute to increase yield. On the other hand B9 produced the least number of siliqua on main shoot. The highest number of seeds (31.27) per siliqua was recorded for the population NRCYS05-03 followed by JYS 14-1. The highest 1000 seed weight was recorded as for the population JYS 14-1 (5.47 g) followed by JT 12-6, JYS 12-2-3, JT 12-21, JT 14-2. The highest seed yield per plant was recorded for the population JT 12-5 (10.43 g), followed by JYS 14-1, JT 12-21and JYS 12-2-3 and highest Biological yield per plant was $(17.83 \mathrm{~g})$ for the population JT 12-5 and JYS 12-2-3 and JYS 14-1 which were at par. Harvest index was maximum (53.51\%) for JT 12-5 followed by JT 12-4, JT 14-2, JYS 14-1, JT 12-1. On view of above 
the result, we can select JT 12-2-1, JT 12-5 JYS 14-1 and JYS 12-2-3 are superior than the other entries based on yield related characters. Also TS38 and their cross derivatives can use in future breeding line for seed production purpose as produce more seed yield as well as biological yield.

\section{Acknowledgements}

The facilities provided by the Assam Agricultural University, Jorhat are gratefully acknowledged.

\section{References}

Ali, N., Javidfar, F., Elmira J.Y., and Mirza, M.Y. 2003. Relationship among yield components and Selection criteria for yield improvement in winter rapeseed (Brassica napus L.). Pakistan J. Bot. 35(2): 167-174.

Aytac, Z., and Kinaci, G. 2009. Genetic variability and association studies of some quantitative characters in winter rapeseed (Brassica napus L.). African J. Biotech. 8(15): 3547-3554.

Barua, P. K. 1992. Genetic analysis of yield parameters in varietal hybrids of Indian rapeseed (Brassica campestris L.). Ph. D. Thesis, Assam Agricultural University, Jorhat.

Chaudhari, N. H., Patel, R. N., Gami, R. A., and Shah, S. K. 2015. Study of combining ability and heterosis for seed yield and seed quality traits in rapeseed (Brassica rapa L.). The Bioscan. 10(4): 1985-1989 (Supplement on Genetics and Plant Breeding).

Dabholkar, A. R. 1999. Elements of Biometrical Genetics. Concept Publishing Company, New Delhi.

DAC, Govt. of India 2014. Department of Agriculture and Cooperation website http://agricoop.nic.in.
DRMR 2016. Directorate of rapeseed-mustard Research (ICAR).

FAO. 2014. Agricultural data. FAOSTAT [Internet]. Food and Agriculture Organization of the United Nations, Rome, Italy. [cited 2016 May 13]. Available from: http://www.fao.org/ economic/ess/ess-publications/ess-y earbook/en.

Ghosh, S.K., and Gulati, S.C. 2001. Genetic variability and association of yield components in Indian mustard. Crop Res. 21: 345-349.

Halder, T., Bhuiyan, M. S. R., and Islam, M. S. 2014. Variability and correlation study of some advanced lines of Brassica rapa. Bangladesh J. Pl. Breed. Genet. 27(1): 25-36.

Jahan, N., Khan, M. H., Ghosh, S., Bhuiyan, S. R., and Hossain, S. 2014. Variability and heritability analysis in F4 genotypes of Brassica rapa L. Bangladesh J. Agril. Res. 39(2): 227-241.

Kahrizi, D., and Alaahvarand, T. 2012. Estimation and interrelationship of genetic variability parameters of some morpho-phenologican traits in Spring Rapeseed (Brassica napus L.). Asian Biol. Sci. 5(7): 358-364.

Khan, S., Farhatullah, Khalil, I. H., Munir, I., Khan, M. Y., and Ali, N. 2008. Genetic variability for morphological traits in F3:4 Brassica populations. Lines. MS Thesis, Dept. of Genetics and Plant Breeding, SAU, Dhaka.

Naznin, S. 2013. Variability, character association and divergence in rapeseed advanced nitrification inhibitors to increase nitrogen use efficiency and to conserve air arid water quality. Common. Soil Sci. Plant Anal. 32: 1051-1070.

Panse, V. G. 1957. Genetics of quantitative characters in relation to plant breeding. Indian J. Genet. 17: 318-329. 
Rahman, I. U., Ahmad, H., Inamullah, Ahmad, S., Abbasi, F. M., Islam, M., and Ghafoor, S. 2009. Evaluation of rapeseed genotypes for yield and oil quality under rainfed conditions of district Mansehra. African Journal of Biotechnology. 8 (24): 6844-6849.

Rakow, G. 2004. Species origin and economic importance of Brassica, p.1-7. In: E. C. Pua, C. J. Douglas. Biotechnology in agriculture and forestry. SpringerVerlag, Berlin-Heidelberg, Germany.

Saifullah, M. 2010. Variability study among the F2 segregants of the intervarietal crosses of Brassica rapa. MS Thesis, Dept. of Genetics and Plant Breeding, SAU, Dhaka.

Singh, D., Mishra, V. K., and Singh, R. P. 2012. Studies on heritability and genetic advance of seed yield and its components in yellow sarson (Brassica campestris L.). Agric. Sci. Digest. 23(1): 69-70.

Tahira, M.H.N., Bashir, S., and Bibi, A. 2006. Genetic potential of canola (Brassica napus L.) varieties under water stress conditions. Caderno de Pesquisa Sér. Bio. 18(2): 127-135.

Ullah, N., Farhatullah, Rahman, H. U., Fayyaz, L., and Amin, N. U. 2015. Genetic variability among advanced lines of Brassica. Pak. J. Bot. 47(2): 623-628.

USDA 2013. United States Department of Agriculture, Foreign Agricultural Service (www.fas.usda.gov).

\section{How to cite this article:}

Smrita Gogoi and Purna K. Barua. 2018. Evaluation of Selected Segregating Populations of Indian Rapeseed (Brassica rapa L.) for Yield and Yield Related Traits. Int.J.Curr.Microbiol.App.Sci. 7(09): 1470-1477. doi: https://doi.org/10.20546/ijcmas.2018.709.176 